\title{
Editorial
}

\section{Autores, revisores e artigos}

Este editorial é para todos os autores e revisores que fazem a Revista Soldagem\&Inspeção. Os diversos trabalhos publicados, pela comunidade de Soldagem e técnicas afins, mostram a capacidade instalada de geração de conhecimento científico e tecnológico. O melhor entendimento de comportamentos e procedimentos, por vezes até já aplicados industrialmente, fundamentados por princípios científicos contribui para o aumento da competitividade da indústria nacional.

Aqueles pesquisadores que obtiveram um reconhecimento do trabalho realizado, também atuam como revisores, trabalho vital para manter a integridade da Revista, contribuir com um padrão de exigência e qualidade em sua especialidade, entre outros. É importante destacar, que apesar de ser um trabalho voluntário, deve seguir exigências específicas para a elaboração de uma crítica construtiva e bem organizada que a revisão de um artigo exige. Em paralelo, o árduo e profissional trabalho dos revisores é ainda balizado por princípios éticos que envolvem confidencialidade, que vai desde a exigência de não revelar sua identidade por comentários pessoais ou nomeação direta, não usar dados dos artigos em avaliação antes de sua publicação, entre outros. Esta dupla atuação de cada pesquisador junto da revista deveria contribuir para aumentar sua exigência quando da submissão dos seus próprios trabalhos, para que não aconteça que o mesmo pesquisador possa parecer ter parâmetros diferenciados para a submissão e para a revisão... Todos são incentivados para que se apliquem sempre padrões de referência exigentes, o grande ganhador é a Revista Soldagem\&Inspeção.

A busca por uma melhoria permanente da revista Soldagem \&Inspeção reflete-se no aumento expressivo de consultas aos artigos publicados e por a revista estar acreditada em diversos indexadores reconhecidos internacionalmente. Continuaremos com o investimento na melhoria da qualidade técnica dos artigos, e considerando pesquisas que mostram que do tempo total que os autores dedicam à elaboração de um artigo, quase $40 \%$ é para atender as normas de formatação de cada revista, em particular no que se refere às referências bibliográficas (http://www.elsevier.com/yourpaperyourway). Seguiremos as tendências globais: a Revista Soldagem \&Inspeção passa a flexibilizar suas normas de formatação em particular para as citações e listagem das referências bibliográficas. Mantendo a consistência em cada artigo, os autores podem selecionar a norma de referência e citação bibliográfica. Um pequeno passo no sentido de permitir que os autores invistam seu tempo no que mais importa, melhorando cada vez mais a qualidade das contribuições que recebemos.

\section{Profa Ana Sofia C.M. d'Oliveira, Ph.D. Editora-chefe}

